\title{
Evaluation of the Indonesian Log Timber Export Prohibition Policy and Proposed Potential Alternative Policies to Minimize Subsidy Allegations
}

\author{
Ayu Sinta Saputri \\ Trade Analysis and Development Agency \\ Ministry of Trade \\ Jakarta, Indonesia \\ ayusinta.saputri@gmail.com
}

\author{
Rizka Isditami Syarif \\ Trade Analysis and Development Agency \\ Ministry of Trade \\ Jakarta, Indonesia \\ rizkasdisy@gmail.com
}

\author{
Herindra Adhi Nusantara \\ Trade Analysis and Development Agency \\ Ministry of Trade \\ Jakarta, Indonesia \\ herindraadhi@gmail.com
}

\begin{abstract}
Wood and paper industry sector become one of the heavily sector which has been charged with trade remedy in Indonesia mostly due to the implementation of log timber export prohibition policy. The implementation of this policy since 2012 has received many trade remedy allegations, particularly subsidy allegations by trading partner countries. This study aims to evaluate the log timber export prohibition policy and propose alternative policies that could minimize the potential for alleged subsidies. The study used some different methodology included normative juridical legal analysis based on the DS491 case study: US Coated Paper, Regulatory Impact Analysis (RIA), and Computable General Equilibrium (CGE) Model to simulate the impact of trade remedy on export prohibition policy, export quota policy, and export duty policy. The results show that the log timber export prohibition policy concluded as a subsidy. While the impact of log timber prohibition export on financial contribution is still debatable. This study recommends better alternative policy option that provide benefits in supporting forest sustainability and the continuity of downstream industries made from wood. That would be done by continuing the log timber export prohibition by adjusting the legal text with World Trade Organization (WTO) principle, namely conservation of natural resources in Article XX GATT 1944 (general exceptions) and clarifying that the control of forests by the government is not dominantly supporting the formation of domestic market prices.
\end{abstract}

Keywords - CGE model, export policies, log timbers, RIA

\section{INTRODUCTION}

WTO agreement caused a significant reduction in tariff barriers among WTO member countries. However, WTO countries impose non-tariff actions as a form of trade restrictions and one of which is a trade remedy. From 19952016, there were 296 trade remedy instruments charged to Indonesia. Based on data from the Directorate of Trade Security [1], as many as 49 cases are included in paper products which are a wood derivative industry. The woodbased industry that consists of the wood industry, wood and woven goods, paper and paper product industry, and furniture industry has an important role in Indonesian economy, that are contribute $1.6 \%$ of national GDP in 2016, accomodate 543 thousand workers in 2015 , and produce of output was 261.5 trillion or $6.2 \%$ of total processed industrial output [2], [3].
The prime factor for the Indonesia's wood-based industry progress is its abundant natural resources in the form of tropical forest with the $8^{\text {th }}$ largest forest area in the world [4]. With this potential, Indonesia was once become the biggest exporter of logs in the world with export value reaching USD 1.2 billion or controlling $41 \%$ of the world log timber market at that time [5]. The large market share to world wood export encourages the illegal logging activities, in which threaten the sustainability of Indonesia's forest and the export illegally so that the domestic wood-based industry suffers from a shortage of raw materials [6]. Therefore, the government issued a $\log$ timber export prohibition in the Joint Decree of Indonesian Forestry Minister No. 1132/KPTS-II/2001 and Indonesia Minister of Industry and Trade No. 292/MPP/KEP/10/2001, Government Regulation No. 34/2002 and Minister Trade Regulation No. 44/MDAG/PER/7/2012.

The implementation of log export prohibition policy led to an increase in the wood-based industry performance but a decrease on welfare of $\log$ timber producer due to the price of domestic logs is lower than the price of international market [6]. In addition, this policy is considered as a form of subsidies from the Indonesian government to the downstream $\log$ timber industry in the form of ease of obtaining raw materials by other countries. At present, the domestic paper industry is facing international trade barrier from several countries including the United States, Australia, Malaysia, Pakistan, India, and Republic of Korea [1]. These countries have given allegations of dumping and imposed high import duties on Indonesian wood derivative products which are feared to be emulated by other trading partner countries not only to paper products but also other wood derivative products. So its important to, as also the objective of this research is, determining better log export policy to minimize subsidy allegations by trading partner countries with regard to environmental aspect and domestic industry sustainability.

\section{METHODS}

The study of evaluating this policy uses qualitative and quantitative approach using primary data and secondary data. Primary data is obtained by conducting interview, limited discussions, forum group discussions, and surveys with Association related with Log and Wood product and Government Institution. Secondary data is taken from 
Statistic Indonesia, World Integrated Trade Solution (WITS), and Global Trade Analysis Project (GTAP) Data Base 9A.

\section{A. Normative Juridical Legal Analysis}

This approach is used to analyze the compatibility of log export prohibition policy with WTO principle. The normative juridical approach is carried out by examining secondary legal library material [7]. Particularly, analysis conducted on primary legal material is Trade Minister Regulation No. 44/M-DAG/PER/7/2012 concerning prohibited items of export and secondary legal material is United States - Anti-Dumping and Countervailing Measures on Certain Coated Paper from Indonesia - Report of the Panel.

\section{B. Computable General Equilibrium (CGE)}

The model used in this study is GTAP that formulated in Hertel [8]. This study use GTAP Data Base 9A. Strategy of aggregation of the economy as following: Indonesia, Australia, Malaysia, Philippines, Thailand, Singapore, Viet Nam, Bangladesh, China, USA, South Korea, Japan, Saudi Arabia, UEA, Iran, Taiwan, India, Pakistan, EU 25 (EU 28 exclude Bulgaria, Croatia, and Romania), and rest of world (all countries exclude above countries). While, the sector aggregation are forestry, wood products, paper products, machine equipment, grains and crops, livestock and meat products, mining and extraction, processed food, textiles and clothing, light manufacturing, heavy manufacturing, utilities and construction, transport and communication, and other services. This GTAP model will be used for alternative policy simulations as one of the steps in the Regulatory Impact Assessment (RIA) as explained in part $\mathrm{C}$ below.

\section{Regulatory Impact Assessment (RIA)}

This method is used to evaluate the log export prohibition policy in Trade Minister Regulation No. 44/MDAG/PER/7/2012 concerning prohibited items of export and recommend better log timber export policy to minimize allegation of subsidies from trading partner countries. These simulations were conducted based on the GTAP method as explained in part $\mathrm{C}$ above. As a process, RIA method that adopted includes the following steps [9], they are (1) identifying the problem; (2) define the objectives; (3) develop main alternative policies; (4) assessment of alternative policy options; (5) selection the policy; and (6) implementation strategy. In assessment step, each alternative policy is analyzed with benefit cost analysis and impact analysis. The impact analysis be simulated into two parts, namely policy alternative without trade remedy imposed and with trade remedy imposed as in Table I and Table II.

TABLE I. SimUlation THE IMPACT OF Alternative POLICIES WithOUT TRADE REMEDY IMPOSED

\begin{tabular}{|c|l|}
\hline Simulation & \multicolumn{1}{c|}{ Alternative Policies } \\
\hline Sim 1 & Export of log timber prohibition \\
\hline Sim 2 & $\begin{array}{l}\text { Export quota of log timber with amount of } 15 \% \text { from } \\
\text { total log production }\end{array}$ \\
\hline Sim 3 & $\begin{array}{l}\text { Export quota of log timber with amount of 30\% from } \\
\text { total log production }\end{array}$ \\
\hline Sim 4 & $\begin{array}{l}\text { Export quota of log timber with amount of } 40 \% \text { from } \\
\text { total log production }\end{array}$ \\
\hline Sim 5 & Export duty of log timber with the amount of $15 \%$ \\
\hline Sim 6 & Export duty of log timber with the amount of $30 \%$ \\
\hline Sim 7 & Export duty of log timber with the amount of $50 \%$ \\
\hline
\end{tabular}

TABLE II. SimUlation the ImPaCt OF Alternative Policies With TRADE REMEdy IMPOSED

\begin{tabular}{|c|l|}
\hline Simulation & \multicolumn{1}{|c|}{ Alternative Policies } \\
\hline Sim 1 & $\begin{array}{l}\bullet \text { Export of log timber prohibition } \\
\text { Paper product that im posed to BMAD/CVD with average of } 48.1 \% \text { from United States and } \\
32.9 \% \text { from Australia }\end{array}$ \\
\hline Sim 2 & $\begin{array}{l}\bullet \text { Export quota of log timber with amount of } 15 \% \text { from total log production } \\
\text { Paper product that imposed to BMAD/CVD with average of } 48.1 \% \text { from United States and } \\
32.9 \% \text { from Australia }\end{array}$ \\
\hline $\operatorname{Sim} 3$ & $\begin{array}{l}\bullet \text { Export quota of log timber with amount of } 30 \% \text {, from total log production } \\
\text { Paper product that im posed to BMAD/CVD with average of } 48.1 \% \text { from United States and } \\
32.9 \% \text { from Australia }\end{array}$ \\
\hline $\operatorname{Sim} 4$ & $\begin{array}{l}\bullet \text { Export quota of log timber with amount of } 40 \% \text {, from total log production } \\
\text { Paper product that imposed to BMAD/CVD with average of } 48.1 \% \text { from United States and } \\
32.9 \% \text { from Australia }\end{array}$ \\
\hline $\operatorname{Sim} 5$ & $\begin{array}{l}\bullet \text { Export duty of log timber with the amount of } 15 \% \\
\text { Paper product that imposed to BMAD/CVD with average of } 48.1 \% \text { from United States and } \\
32.9 \% \text { from Australia }\end{array}$ \\
\hline $\operatorname{Sim} 6$ & $\begin{array}{l}\bullet \text { Export duty of log timber with the amount of } 30 \% \\
\text { Paper product that imposed to BMAD/CVD with average of } 48.1 \% \text { from United States and } \\
32.9 \% \text { from Australia }\end{array}$ \\
\hline $\operatorname{Sim} 7$ & $\begin{array}{l}\bullet \text { Export duty of log timber with the amount of } 50 \% \\
\text { Paper product that imposed to BMAD/CVD with average of } 48.1 \% \text { from United States and } \\
32.9 \% \text { from Australia }\end{array}$ \\
\hline
\end{tabular}

\section{RESULT AND DISCUSSION}

A. Analysis of compatibility law of the log export prohibition with WTO Agreement: Case Study DS 491: US-Coated Paper

An investigation by US government authority cocluded that the Indonesian log export prohibition policy included subsidies that were countervailable to the Indonesian paper industry and exceeded de minimis so that imported paper products (certain coated paper) from Indonesia were charged to countervailing duty (CVD). Indonesia took steps to bring the US's investigation result to WTO Dispute Settlement Body (DSB) that aims to test its consistency with Agreement on Subsidies and Countervailing Measusres (ASCM). Then, the dispute case that called DS491 through consultation conducted on June 25, 2015 but did not resolve this issue. Furthermore, Indonesia submitted a request for the formation of a panel that formed on September 28, 2015.

Indonesia did not appeal the results of the DS491 case panel so that the panel report approved by DSB WTO became jurisprudence, which could be referred to as the 
consistency of the log timber export prohibition with ASCM. With the results of the DS491 case, it can be interpreted as follows (1) Existence of subsidies can still be debated because the panel only hypothesizes. The panel refused to analyze and decide whether or not there were subsidies in the form of financial contributions, as a result of the log export ban. For Indonesia, there is still room to argue that the ban on log export is not a financial contribution, but requires the construction of arguments that are equipped with facts and legal evidence (2) Subsidies on the log timber export prohibition are proven specific because they are given to companies with a limited amount (3) The benefit calculation by the US subsidy investigating authority is correct, with a note that the financial contribution exists from the log export prohibition policy. Based on these results, the policy recommendations that can be taken by the government are continuing a log timber export prohibition policy or substituting other policies.

\section{B. Evaluate Alternative Policies}

1) Identifying the problem. The Indonesian log timber export prohibition policy faced accusation of subsidy from the US that disputed in the DS491 case. This is feared to trigger other trading partner countries do the same charge. On the other hand, this policy is implemented to control the exploitation of natural resources and ensure the availability of raw materials for domestic market because it also became the focus of the log export policy.

2) Define the objectives: In general, the policy must be able to minimize the subsidy allegation for Indonesian wood derivative product. In specific, the log timber export policy has the following objectives: decelerate deforestation or environmental damage, establish the fair prices between the upstream and downstream sectors, ensure the availability of log timber for domestic market, and minimize the smuggling of $\log$ timber.

3) Develop main alternative policies: To achieve the objectives, several suggested policy options are the prohibition on log timber exports, the implementation of $\log$ export quotas, and the imposition of log timber export duties.

a) Prohibition on Log Timber Export: The objective of this policy is to control the exploitation of natural resources, in this context is the deforestation rate. Based on Indonesia's deforestation rate data, the highest deforestation in 1996-2000 where in 1998, in which the government implemented export duty with the amount of $40 \%$. Then, since the export prohibition policy back to implemented in 2001 the deforestation rate decrease significantly as in Figure 1. Therefore, the prohibition on $\log$ timber export policy effectively decelerate deforestation rate.

b) Implementation of Log Timber Export Quota: This policy allows the log export based on wood balance. If the wood balance is deficit, the export are not permitted vice versa if the wood balance is surplus, the export are permitted. Thus, the government needs to develop a wood balance, namely the potential for production, stock, domestic industry consumption, and stock reserves for future period.

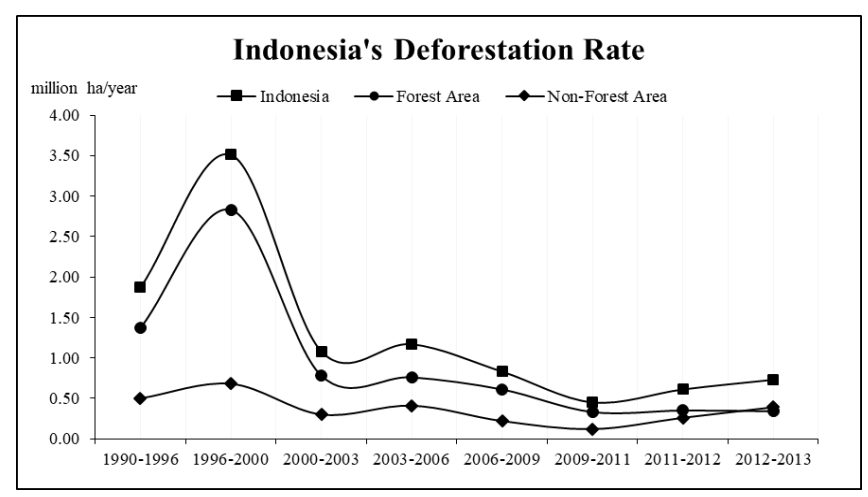

Source: Indonesian Natural Forest Monitoring System Presentation

Fig. 1. Indonesia's Deforestation Rate

c) Imposition of Log Timber Export Duty: This policy is not specifically regulated or prohibited by GATT 1994. As such, this policy is an instrument that is permitted by the WTO.

d) Assesment of alternative policy options. The assessment of benefit and cost is reviewed from the perspective of government, society, consumers, business people, and the economy as a whole. Consultation with relevant stakeholders is the key of this analysis. Stakeholder for this analysis consist of Ministry of Forestry; Ministry of Industry; and several Association related to forestry, log, and wood product. In brief, the benefit and cost of the three alternative policies are presented in Table III.

TABLE III. BENEFIT AND COST ANALYSIS

\begin{tabular}{|c|c|c|}
\hline $\begin{array}{l}\text { Alternative } \\
\text { Policies }\end{array}$ & Benefit & Cost \\
\hline $\begin{array}{l}\text { Prohibition } \\
\text { on Log } \\
\text { Timber } \\
\text { Export }\end{array}$ & $\begin{array}{l}\text { Ensure the availability of } \\
\text { raw logs for domestic } \\
\text { market } \\
\text { - Absorb the employment } \\
\text { in downstream sectors } \\
\text { - Increase export of } \\
\text { derivative wood } \\
\text { products } \\
\text { Quite effective on } \\
\text { pushing the rate of } \\
\text { deforestation } \\
\text { - Ease of implementation } \\
\end{array}$ & $\begin{array}{l}\text { - The price of domestic log is } \\
\text { lower than the price of } \\
\text { international market that can } \\
\text { reduce investment in upstream } \\
\text { sector so the log production in } \\
\text { domestic decreased } \\
\text { - Potential to be accussed subsidy } \\
\text { and particular market situation } \\
\text { from other countries for wood } \\
\text { derivative products } \\
\text { - Encourage the log timber export } \\
\text { illegally }\end{array}$ \\
\hline $\begin{array}{l}\text { Implementati } \\
\text { on of Log } \\
\text { Timber } \\
\text { Export Quota }\end{array}$ & $\begin{array}{l}\text { - More effective to ensure } \\
\text { the availability of raw } \\
\text { logs than export duty } \\
\text { option, but less effective } \\
\text { than the export } \\
\text { prohibition } \\
\text { - It is estimated that the } \\
\text { policy is quite effective } \\
\text { to restrain the rate of log } \\
\text { timber export ilegally } \\
\text { compared to export } \\
\text { prohibition option }\end{array}$ & $\begin{array}{l}\text { - Quite difficult to be implemented } \\
\text { because it must arrange wood } \\
\text { balance and needs to verified, } \\
\text { like the sugar balance case } \\
\text { - It is feared there will be abuse of } \\
\text { authority in quota allocation } \\
\text { - Potential to be accussed subsidy } \\
\text { for wood derivative products } \\
\text { - Risk to be disputed in the form } \\
\text { of quantitative restriction (QR) } \\
\text { - Less effective in realizing fair } \\
\text { prices between upstream and } \\
\text { downstream sectors } \\
\text { - Less effective in reduce the rate } \\
\text { of deforestation compared to } \\
\text { export prohibition option }\end{array}$ \\
\hline $\begin{array}{l}\text { Imposition of } \\
\text { Log Timber } \\
\text { Expor Duty }\end{array}$ & $\begin{array}{l}\text { - The permitted } \\
\text { instrument by WTO } \\
\text { principle } \\
\text { - Establish a reasonable } \\
\text { price between upstream } \\
\text { and downstream sectors } \\
\text { - Quite effective on } \\
\text { pushing log timber } \\
\text { export ilegally } \\
\text { - Increase the state } \\
\text { revenues }\end{array}$ & $\begin{array}{l}\text { - Downstream industry may get } \\
\text { difficult on raw logs stock that } \\
\text { will affect to competitiveness of } \\
\text { domestic industry } \\
\text { - Accelerate the rate of } \\
\text { deforestation as happened in } \\
1998 \\
\text { - Further studies are needed } \\
\text { regarding the optimal scale of the } \\
\text { custom duty that can restrain the } \\
\text { deforestation rate }\end{array}$ \\
\hline
\end{tabular}


The assessment of impact analysis conducted on macroeconomic indicator is GDP growth and Indonesian export growth and output for wood and paper products. The simulation results of the impact of alternative policies without trade remedy imposed by trade partner countries are listed in Table IV.

TABLE IV. Simulation the ImPaCt OF Alternative Policies Without Trade Remedy IMPOSITION By TRADE PaRTner Countries

\begin{tabular}{|c|c|c|c|c|c|c|c|}
\hline \multirow{3}{*}{ Policy Impact (\%) } & \multicolumn{7}{|c|}{ Alternative Policies } \\
\hline & \multirow{2}{*}{$\begin{array}{c}\text { Export Prohibition } \\
\text { Sim } 1\end{array}$} & \multicolumn{3}{|c|}{ Export Quota } & \multicolumn{3}{|c|}{ Export Quota } \\
\hline & & $\operatorname{Sim} 2$ & $\operatorname{Sim} 3$ & $\operatorname{Sim} 4$ & $\operatorname{Sim} 5$ & $\operatorname{Sim} 6$ & $\operatorname{Sim} 7$ \\
\hline GDP growth & -0.0082 & -0.0028 & -0.0016 & -0.0011 & -0.0007 & -0.0023 & -0.004 \\
\hline \multicolumn{8}{|c|}{ Indonesian export growth } \\
\hline Wood product & 0.83 & 0.7 & 0.57 & 0.49 & 0.41 & 0.65 & 0.8 \\
\hline Paper product & 0.13 & 0.1 & 0.08 & 0.07 & 0.06 & 0.1 & 0.12 \\
\hline \multicolumn{8}{|l|}{ Indonesian output } \\
\hline Wood product & 0.33 & 0.28 & 0.23 & 0.2 & 0.26 & 0.26 & 0.31 \\
\hline Paper product & 0.05 & 0.04 & 0.03 & 0.03 & 0.02 & 0.04 & 0.05 \\
\hline
\end{tabular}

Based on the simulation results, the three log timber export policy options led to decline in GDP. The highest decline is export prohibition policy with amount of $0.008 \%$ while the lowest decline is the $15 \%$ export duty policy with amount of $0.0007 \%$. In export growth indicator, the highest growth of wood and paper products sectors are $0.83 \%$ and $0.13 \%$ in the export prohibition policy while the other two policies have lower export growth results, namely export of wood products between $0.41 \%-0.80 \%$ and export of paper products between $0.006-0.12 \%$. The log export prohibition policy also has the highest yield on output of wood and paper products which reached $0.33 \%$ and $0.05 \%$. These three policy options still have the risk of being accused of subsidies by trading partner countires. Therefore, this study also simulates the impact of alternative policies if the trading partner country impose trade remedy as listed in Table V.

TABLE V. Simulation the ImPaCt OF Alternative Policies Without Trade Remedy Imposition By TRADE Partner Countries

\begin{tabular}{|c|c|c|c|c|c|c|c|}
\hline \multirow{3}{*}{ Policy Impact (\%) } & \multicolumn{7}{|c|}{ Alternative Policies } \\
\hline & \multirow{2}{*}{$\begin{array}{c}\text { Export Prohibition \& } \\
\text { Trade Remedy } \\
\text { (Sim 1) }\end{array}$} & \multicolumn{3}{|c|}{ Export Quota \&Trade Remedy } & \multicolumn{3}{|c|}{ Export Duty \&Trade Remedy } \\
\hline & & $\operatorname{Sim} 2$ & Sim 3 & $\operatorname{Sim} 4$ & Sim 5 & Sim 6 & $\operatorname{Sim} 7$ \\
\hline GDP growth & -0.0093 & -0.0041 & -0.0029 & -0.0024 & -0.002 & -0.0036 & -0.0053 \\
\hline \multicolumn{8}{|l|}{ Indonesian export growth } \\
\hline Wood product & 1.15 & 1.03 & 0.90 & 0.82 & 0.74 & 0.98 & 1.1 \\
\hline Paper product & -6.16 & -6.18 & -6.2 & -6.21 & -6.23 & -6.19 & -6.17 \\
\hline \multicolumn{8}{|l|}{ Indonesian output } \\
\hline Wood product & 0.44 & 0.39 & 0.34 & 0.31 & 0.28 & 0.38 & 0.42 \\
\hline Paper product & -1.90 & -1.90 & -1.91 & -1.92 & -1.92 & -1.91 & -1.9 \\
\hline
\end{tabular}

Based on the simulation results, the trade remedy imposition by other countries on Indonesia paper products also causes decline in GDP for the three policy options. The highest decline with amount of $0.0093 \%$ occured in export prohibition policy. Meanwhile, the export quota option with quota of $15 \%$; $30 \%$; and $40 \%$ in succession has a decrease of $0.0041 \%$; $0.0029 \%$; and $0.0024 \%$ so that the higher export quota the lower the declining in GDP. Contrarily, in export duty imposition policy, the higher export duty the higher decline in GDP.

In the terms Indonesian export growth and output, the imposition of trade remedy for paper products led to decline in export growth and output for paper products itself but an increase in wood products sector. The export prohibition policy is the lowest decline in paper products by $6.16 \%$ and the highest increase in wood products by $1.15 \%$ compared to the other two policy options. This simulation also shows similar results in increasing output of wood products and decreasing output of paper products. The highest increase in wood products output occurred in the export prohibition policy, while the lowest decrease in paper products output occured in the export prohibition policy, the export quota policy by $15 \%$, and the export duty by $50 \%$.

4) Selection the policy. Based on the assessment result in previous stage, the imposition of log timber export duty can minimize the accused of subsidy but has not good impact on deforestation and microeconomic indicator. So, the effective and efficient option is the log timber export prohibition policy. This policy has a better advantage compared to the other two policy options in the ability of decelerate deforestation rates and the availability of raw logs for domestic market. In addition, this policy causes higher exports and output for wood products. 
5) Implemetation strategy. The disadvantage of this $\log$ timber export prohibition policy is there is still possibility of subsidies so that minimizing strategy is needed with ensure the consistency of policy objectives in policy considerations, that can be justified by WTO principle: conservation of natural resources in Article XX GATT 1994 (general exceptions).

\section{CONCLUSIONS AND RECOMMENDATIONS}

\section{A. Conclusions}

This paper revealed that log timber export prohibition policy listed in Trade Minister Regulation No. 44/MDAG/PER/7/2012 concerning prohibited items is still valid. The existence of subsidies to this policy can still be debated because the WTO DBS panel only hypothesizes in terms of financial contributions, but it requires the construction of arguments that are equipped with facts and legal evidence. The log timber export prohibition policy is quite effective in achieving objectives and easy to implemented compared to the export quota and export duty options. Thus, the export prohibition option is still favored. However, this policy still has potential to be accused of subsidies so that the improvements need to be made as in the recommendations section.

\section{B. Recommendations}

The prohibiton of log timber export currently should be improved by determining the scope of products that are prohibited from exporting (raw material of paper permitted), applying requirements for log timber exports as must be done by holders of business permit for Forest Timber Product Utilization - Industrian Plantation Forest (Izin Usaha Pemanfaatan Hasil Hutan Kayu Hutan Tanaman Industri, IUPHHK-HTI), and exporting conducted on the some selected ports. Thus, ministries and agencies with related stakeholder need to be involved in formulating the requirement and mechanism for pulp log export. Beside that, the government needs to ensure the consistency of policy objectives in policy considerations, that can be justified by WTO principle: conservation of natural resources in Article XX GATT 1994 (general exceptions). The government must also clarify that the control of forests by the government is not dominantly supporting the formation of domestic market prices.

\section{ACKNOWLEDGMENT}

This research was supported by Trade Analysis and Development Agency, Ministry of Trade. We thank our colleagues from Trade Security Unit of Foreign Trade Research Center, they are Aditya Paramita Alhayat, Ayu Wulandani, and Arinda Nur Latifah that insight and expertise that greatly assisted the research, although the may not agree with all of the interpretations/conclusions of this paper.

\section{REFERENCES}

[1] Directorate of Trade Security, Ministry of Trade of the Republic Indonesia, unpublished, 2017.

[2] Statistics Indonesia, Indonesia's Quarterly GDP 2014-2018, ID: 2018. Badan Pusat Statistik (BPS), PDB Indonesia Triwulanan 2014-2018, Badan Pusat Statistik, ID: 2018.

[3] Statistics Indonesia, Statistics of Large and Medium Industries 20082015, ID: 2017. Badan Pusat Statistik (BPS), Statistik Industri Besar dan Sedang 2008-2015, Badan Pusat Statistik, ID: 2017.

[4] Worldbank, Forest area (sq.km), Available at: https://data.worldbank.org/indicator/AG.LND.FRST.K2, 2018

[5] M. Prisilia, Indonesian Log Export Duty for the Optimization of the Pulp Industry. ID: Bogor Agricultural University, 2015. M. Prisilia, Bea Keluar Ekspor Kayu Log Indonesia untuk Optimalisasi Industri Pulp. ID: Institut Pertanian Bogor, 2015

[6] B. Simangunsong, and B. Nugroho, Study on Revocation of Export Prohibitions and the Imposition of Export Taxes on Indonesian Timber Plantation Forests, unpublished, Ministry of Forestry, ID: Directorate General of Business Development of the Ministry of Forestry, 2013. B. Simangunsong, and B. Nugroho, Kajian Pencabutan Larangan Ekspor dan Pengenaan Pajak Ekspor Kayu Bulat Hutan Tanaman Industri Indonesia, unpublished, Ministry of Forestry, ID: Directorate General of Business Development of the Ministry of Forestry, 2013

[7] ZD. Zaini, Implementation of Normative Juridical Approaches and Sociological Normative Approaches in Legal Science Research, Legal Institutions, vol. 6 No. 2, pg. 117-132, 2011. ZD. Zaini, Implementasi Pendekatan Yuridis Normatif dan Pendekatan Normatif Sosiologis dalam Penelitian Ilmu Hukum, Pranata Hukum, vol. 6 No. 2, pp. 117132,2011

[8] TW. Hertel, Global Trade Analysis: Modelling and Applications. Cambridge University Press, MA: Cambridge, 1997.

[9] Ministry of National Development Planning, Development and Implementation of Regulatory Impact Analysis (RIA) Methods for Assessing Policies (Regulations and Non-Regulations) at the Ministry of NDP/ Bappenas. Available at: http://birohukum.bappenas.go.id/ 2011. Bappenas, Pengembangan dan Implementasi Metode Regulatory Impact Analysis (RIA) untuk Menilai Kebijakan (Peraturan dan Non Peraturan) di Kementerian PPN/Bappenas. Available at: http://birohukum.bappenas.go.id/ 2011 